\title{
The effects of chess education on mathematical problem solving performance
}

\author{
Anita Misetáné Burján
}

\begin{abstract}
We investigate the connection between the "queen of sciences" (mathematics) and the "royal game" (chess) with respect to the development of mathematical problem solving ability in primary school education (classes 1-8, age 7-15) where facultative chess education is present. The records of the 2014 year's entrance exam in mathematics obligatory for the enrollment to secondary grammar schools in Hungary - are compared for the whole national database and for the results of a group containing chess-player students. The problems in the tests are classified with respect to the competencies needed to solve them. For the evaluation of the results we used standard mathematical statistical methods.
\end{abstract}

Key words and phrases: chess education, mathematical competence, problem solving.

ZDM Subject Classification: D60.

\section{Introduction}

The application of chess in the education is becoming a practice in more and more countries. For example, in New York City within the framework of Chess in the Schools program [3] the introduction of chess in education has been a real success since 1986 . Throughout its history more than 500,000 pupils participated in the program. The improvement of concentration, strategy, humility, self-confidence and flexible thinking is the key to the success of the pupils. A strong point of the program is that it gives opportunity for pupils to learn chess within the framework of public education. 
In Hungary, the education of chess earlier appeared as an extracurricular activity.There it was possible to select talented children, and they could improve themselves with the help of regional chess schools or chess clubs. There also were students who played chess simply for their own entertainment, and did not want to play chess professionally. The National Core Curriculum [7] brought a revolutionary change with making chess an optional subject in schools. One argument for making chess a subject in schools is that the thinking of a chess player is complex, so knowing it can be beneficial for a large variety of problems or tasks. According to Judit Polgár, chess is the most ancient game of history the educational tool of the future [14]. The "Sakkpalota" (Chess Palace) program designed by her is a complex method for skill improvement, with the help of which children can be introduced to the world of conscious knowledge acquisition at the end of the kindergarten and at the beginning of elementary school. The program does not primarily teach chess but it teaches with chess.

In the present paper we study the transfer effects of chess education to mathematical problem solving performance.For this, we evaluate the results of a Hungarian national entrance test in mathematics, written by students of age 14, to enter secondary grammar schools. We point out differences between the results of a group of chess players and average students. According to our investigations these differences are, at least partly, due to chess education. We emphasize that the actuality of the subject and the up-to-date research and results in the field yield a motivation for such a study.

\section{Theoretical background}

The "general" skill improvement effect of chess education is well-known from the literature. The development of kindergarteners and primary school students was described by Duró in [5] and [6]. Szilágyi and Duró in [19] present a psychological study on the thinking and personality improving effects of chess, and Csíkos connects chess, metacognition and the novice-expert terms in a complex way (see [4]). According to him the experts can be characterized by two important things: they possess a huge amount of knowledge, and they use these consciously and rapidly in the process of problem solving. Their thinking consists of many automatic elements, they are able to make quick judgements and their thinking is conscious. When interpreting new situations, we recall our previous knowledge and experiences. According to Mérő [10], the building blocks of complex thinking are the schemes. Knowing schemes is inevitable in chess, as well. Grand masters 
recognize 50,000 to 100,000 schemes. Simon and Gilmartin realized [17], that chess masters store a large number of chess positions, associating the best moves to them. An experienced mathematical problem solver can also build up and store a huge number of schemes in her/his memory. This makes it possible to categorize the problems from some topic according to the steps of their solutions. The mathematical problem solving skill improves by learning many problem solving strategies, met by relevant mathematical examples [18]. There are several similarities between good chess players and good mathematical problem solvers. Some elements of chess can be utilized in the mathematical thinking of students as an opportunity for learning such schemes.

According to Gik, the comparison of mathematics and chess as human activities is an interesting thing, which deserves attention in itself [8]. Pedagogical experiments measuring the effects of chess education on mathematical problem solving abilities have several viewpoints. The ages of the studied groups of children are different, and in particular, many researchers investigate pupils below average abilities. Hong and Bart [9], investigating students of age 8-12, having weak abilities (close to failing), concluded that chess education does not play a role in cognitive development. Scholz et al. [16] obtained different results for students of low IQ, having learning problems, of age 10. They experienced improvement for simple addition and counting. Kazemi, Yektaryar and Abad (cited by Bart [2]) reported on positive effects. The members of the chess player group achieved much higher points on the usual mathematics exam, than the members of the other group. The authors concluded that chess education significantly develops the metacognitive capacity of pupils. According to Trinchero, chess training implies a small, but measurable improvement[20]. Sala, Gorini and Pravettoni report on positive correlation [15], however, they also say that there are only little data proving the improving effects of chess education on cognitive abilities. Because of chess education and online mathematical training, it cannot be guaranteed that the positive change is due to the special factor of chess. According to their opinion, the special abilities of a chess player are context-dependent, and transfer has a low probability. Barett and Fish write that chess abilities are domain specific, they cannot be readily transferred, and this also depends on the method of chess education [1].

The research of the topic is not at all finished. The related pedagogical experiments take a lot of time, and to measure the effect is rather problematic. 


\section{Research question and hypothesis}

We investigate how the education of chess affects the improvement of mathematical thinking and problem solving performance of students. According to our hypothesis, the early chess education and training for chess competitions definitely help the complex development of mathematical competences. Already the performance of amateur chess players - who participated in chess lessons one day a week at least for a year - on a mathematical skill measurement test is better.

\section{Methodology}

We study the thinking of 8th graders (age 14) during the solution of entrance exam tests in mathematics, in a given time frame. We analyse the mathematical exercises of the central mathematical entrance exam [12] of the 9th grade admission in the 2013/2014 school year, which was written by 51,100 8th graders on 18 January, 2014. We use the official database for our research. In that year $59 \%$ of the 8 th graders wrote the central admission exam of mathematics. The exam was completed by those children who wanted to continue their studies in secondary schools that require the entrance exam from Hungarian language and mathematics. It contains ten exercises that are solved by the pupils (without using calculator) in 45 minutes. The maximal score is 50 . The main goal is to differentiate the students based on their mathematical score which serves as the base of the high school admission hierarchy. The other goal is the measurement of the required basic skills and competences for successful high school learning [13]. The objectivity of the process is guaranteed by that the tests are written in the schools where the students want to enter, and that the tests are evaluated according to a central correction key.

First we introduce a small group. Our experimental group consisted of twenty students (about the same number of boys and girls), of grade 8 (age 14-15), all writing the above mentioned entrance exam. The children were students of a small town in Somogy county. They learned mathematics according to the standard curriculum, but in grade 8 they had an extra preparatory class in mathematics. All the members of the group knew the basic rules of chess. They also had the possibility to take part in the special chess course in the school. Some of the students attended this chess course only for a year. At grade 8, all members of the experimental group received some chess education, since in the frame of the preparatory class they often met some chess problem or mathematical 
problem related to chess. On the other hand, none of the children was a high level professional chess player. The group contained chess-players participating in national chess championships, amateur chess-players participating in school championships and students knowing the basic rules of chess, and playing occasionally with friends and family members. We performed our research in natural circumstances: the students participating in the experiment did not know about it, they prepared for the mathematical exam in the usual way, and beside that they played chess (on different levels).

Then we shall use the nationwide database of the entrance exam to compare the performance of the whole population with the performance of our group (hereafter referred to as "Chess-players group").

\section{Presentation of the results}

First we compare the performance of the chess-players group to the national results.Then we also investigate the question that in which type of problems did the chess player group achieved better scores than the nationwide average. To answer this question we perform a quantitative analysis. The access to the national database makes possible detailed comparisons, which are also discussed.

\section{Comparison of the records in the whole national database with the} scores of the Chess-players group

We assume the two populations (the group of chess players and the group of all students who wrote the test) are both approximately normally distributed, with known variances.So we may apply u-test to decide whether the difference of their means is significant on the usual (95\%) level or not. Table 1 contains the data of the two populations, required for the $u$-test.

Table 1. Sizes, means and standard deviations of the national- and chess players' populations

\begin{tabular}{|c|c|c|}
\hline & National database & Chess-players \\
\hline$n$ (size) & 51080 & 20 \\
\hline$m$ (mean) & 20.314 & 33.000 \\
\hline standard deviation & 10.508 & 7.416 \\
\hline
\end{tabular}


Null hypothesis, $H_{0}$ : the mean of the Chess-players and of the whole population are statistically equal (The difference is caused only by random effects.)

Significance level: $5 \%$, corresponding $u$ value: $u_{p / 2}=u_{0,025}=1.96$. Because the evaluated $u=7.647>u_{p / 2}$, we reject H0: the mean of the Chess players' sample is significantly larger than the national one.

To prepare the histogram of the cumulative relative frequencies (Figure 1), the test scores of each populations were divided into ten subintervals (0-5, 6-10, 11-15, 16-20, 21-25, 26-30, 31-35, 36-40, 41-45, 46-50). The frequency-diagrams show the data of national population as dark-grey columns, and the data of Chessplayers as light-grey ones.

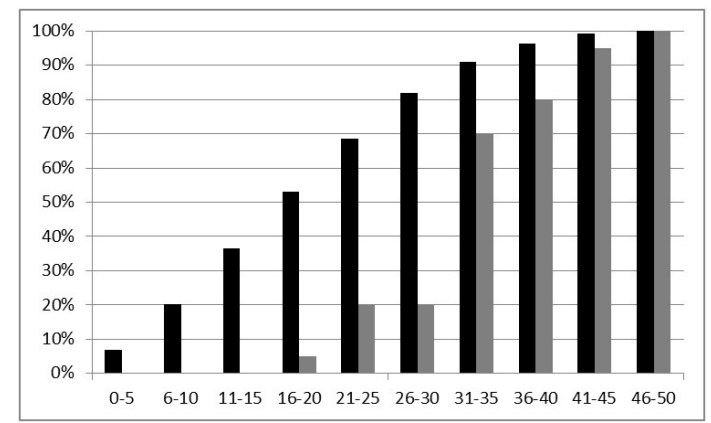

Figure 1. Histogram of cumulative relative frequencies

The incidence of students belonging to the experimental group (i.e. the chess players) is $80 \%$ in the "best" (7-10) groups (scores between 31 and 50), and only $20 \%$ of the students belongs to "lower" (or rather "middle": 4-6) groups (scores between 16 and 30). Out of the national population $20 \%$ of the students belong to the "lowest" (1-2) groups (scores between 0 and 10). In this year the scores of more than $2 / 3$ of the students are in the first 5 interval considering the whole national DB, which means, that they achieved in the investigated test of mathematics less than or equal to $50 \%$ of the maximum score.

\section{Comparison of the entrance exam results of the experimental group and two other groups}

In this section we compare the entrance exam results of the chess-player group with two other groups (A and B). We chose these groups from the national 
database after they wrote the entrance exam, so they did not know that they are being observed. When we chose the groups, the following factors were taken into consideration. We selected students from two other nearby schools, where there is no chess education, but the number of their weekly mathematics lessons was similar to that in our group. The county of the three elementary schools belongs to the mid-range based on the national results; we are not talking about mathematics special town schools.

We assumed that the groups are samples from independent populations having normal distribution. To compare the means (averages) of the samples we used Student's $t$-test. Table 2 contains the required input data of the $t$-test. We investigated whether the difference of the two means comes from random effects, or it is caused by the assumed effect of chess education.

Table 2. Size, mean and standard deviation values of the samples

\begin{tabular}{|c|c|c|c|}
\hline & Chess-players & Group A & Group B \\
\hline$n$ (size) & 20 & 37 & 22 \\
\hline$m$ (mean) & 33.000 & 21.595 & 24.455 \\
\hline$s$ (standard deviation) & 7.609 & 8.713 & 10.809 \\
\hline
\end{tabular}

\section{Chess-players vs. Group A}

Null hypothesis, $H_{0}$ : there is no significant difference between the means. Student's $t$-test value: $t=4.923$; degree of freedom: $d_{f}=20+37-2=55 ; t$ value of the $95 \%$ significance level: $t_{95}=2.000$. We reject $H_{0}$, because $t>t_{95}$. It means that the difference between the means can be considered to be significant.

\section{Chess-players vs. Group B}

Null hypothesis, $H_{0}$ : there is no significant difference between the means. Student's $t$-test value: $t=2.935$; degree of freedom: $d_{f}=20+22-2=41 ; t$ value of the $95 \%$ significance level: $t_{95}=2.021$. We reject $H_{0}$, because $t>t_{95}$. It means that the difference between the means can be considered to be significant.

The results of the randomized experiments show, that the sample mean of the Chess-players is significantly better (larger) than the sample mean of any of the groups.

We made a further comparison. The 20 best results out of the 37 ones of the Group A were selected, and we performed the $t$-test again with the same 
$H_{0}$ : there is no significant difference between the mean of the Chess-players and the mean of the restricted Group A. The result was the following. $m=27.750$; $s=5.466 ; t=2.506 ; d_{f}=20+20-2=38 ; t_{95}=2.021$. Because $t>t_{95}$, we again had to reject $H_{0}$ : the mean of the Chess-players group is still significantly larger than the mean of the restricted Group A, which contains the best result having 20 students of the original group.

These tests support our original hypothesis that chess education helps the development of mathematical problem solving ability.

\section{Investigations with respect to mathematical competence-areas}

In this chapter we compare the results achieved on nationwide level with the results achieved by the experimental group. Our goal is to identify the mathematical competence areas, where the scores of chess players are significantly better than the nationwide average. We chose the components of mathematical competences and skills required for the solution of the problems (Table 3) according to the partition of Vidákovich intelligence factor analysis (see [21])

Table 3. Mathematical competence areas according to the partition of Vidákovich

\begin{tabular}{|c|c|c|c|c|}
\hline Facilities & Thinking skills & $\begin{array}{l}\text { Communicational } \\
\text { skills }\end{array}$ & $\begin{array}{l}\text { Skills for } \\
\text { acquiring } \\
\text { knowledge }\end{array}$ & Learning skills \\
\hline counting & ordering & $\begin{array}{l}\text { the words of spatial } \\
\text { relationships }\end{array}$ & $\begin{array}{l}\text { problem } \\
\text { sensitivity }\end{array}$ & attention \\
\hline calculation & combinativity & $\begin{array}{l}\text { reading } \\
\text { comprehension }\end{array}$ & $\begin{array}{l}\text { problem } \\
\text { representation }\end{array}$ & $\begin{array}{l}\text { part-whole } \\
\text { perception }\end{array}$ \\
\hline $\begin{array}{l}\text { quantitative } \\
\text { reasoning }\end{array}$ & deduction & $\begin{array}{l}\text { spatial } \\
\text { visualization, } \\
\text { spatial perception }\end{array}$ & $\begin{array}{l}\text { originality, } \\
\text { creativity }\end{array}$ & memory \\
\hline $\begin{array}{l}\text { estimation, } \\
\text { measurement }\end{array}$ & induction & $\begin{array}{l}\text { drawing, } \\
\text { representation }\end{array}$ & problem solving & $\begin{array}{l}\text { staying at the } \\
\text { problem }\end{array}$ \\
\hline unit conversion & $\begin{array}{l}\text { probabilistic } \\
\text { reasoning }\end{array}$ & & metacognition & $\begin{array}{l}\text { problem } \\
\text { solving speed }\end{array}$ \\
\hline $\begin{array}{l}\text { solution of } \\
\text { word problems }\end{array}$ & $\begin{array}{l}\text { arguing, } \\
\text { proving }\end{array}$ & & & \\
\hline
\end{tabular}

Table 4 contains the statistical descriptors of the population, determined by the achieved scores (to each problem) in the test [13]. We compared the scores 
of the Chess-players (CP) with the scores given in the whole national database $(\mathrm{nDB})$.

Table 4. Scores of nDB and CP group, problem-by-problem

\begin{tabular}{|l|l|l|l|l|l|l|l|}
\hline $\begin{array}{l}\text { Number } \\
\text { of the } \\
\text { exercise }\end{array}$ & MaxPoint & \multicolumn{2}{|l|}{$\begin{array}{l}\text { Percentage of } \\
\text { achieved points }\end{array}$} & \multicolumn{2}{|c|}{ Median } & \multicolumn{2}{l}{ Modus } \\
\hline & & nDB & CP & nDB & CP & nDB & CP \\
\hline 1 & 4 & 48,60 & 83,75 & 2 & 4 & 0 & 4 \\
\hline 2 & 4 & 62,56 & 90,00 & 3 & 4 & 4 & 4 \\
\hline 3 & 5 & 63,18 & 84,00 & 3 & 5 & 5 & 5 \\
\hline 4 & 6 & 67,88 & 90,83 & 4 & 6 & 6 & 6 \\
\hline 5 & 5 & 43,63 & 82,00 & 2 & 5 & 0 & 5 \\
\hline 6 & 4 & 72,71 & 86,25 & 3 & 4 & 4 & 4 \\
\hline 7 & 6 & 21,68 & 40,83 & 1 & 2 & 0 & 2 \\
\hline 8 & 6 & 12,91 & 55,83 & 0 & 5 & 0 & 6 \\
\hline 9 & 5 & 13,56 & 30,00 & 0 & 1 & 0 & 0 \\
\hline 10 & 5 & 15,97 & 31,00 & 0 & 2 & 0 & 2 \\
\hline Sum & 50 & 40,64 & 66,00 & 20 & 32,5 & 15 & 32 \\
\hline
\end{tabular}

Considering the total scores, we see, that the nationwide mean was $40,64 \%$ while the Chess-players mean was $66 \%$. For the median we have $M_{n D B}=15<$ $M_{C P}=32$. It is worth to note that in $\mathrm{nDB}$ for 6 problems out of 10 , the modus the most frequently occurring score - is zero, while in the chess players' group the modus is zero only in problem 9 . If we take in account the fact, that the average of the achieved scores in the last four problems were in both groups significantly lower than the those of the first six ones, we may assume, that a time-factor influenced the individual scores of the problems, too, especially for students, who were unable to manage their time. Anyway, the last four exercises were more complex ones from the topics of geometry, algebra and number theory.

Based on the data of Table 4, we chose three problems (Figure 2, Figure 4 and Figure 6), where there was more than 35\% difference between the means of the achieved scores of the two groups and the difference between the medians was at least two, between the mode values at least four. We analyze these exercises based on the content of the problems and on the competence areas required for solving them, as well. 
Exercise 1 On the figure below on each arrow there is an operator (addition, subtraction, multiplication or division). Carry out the operation with the number you see at the starting point of the arrow. The result of the operation will be the number, the arrow is pointing at. In the case of the first operation: $\frac{2}{5} \cdot 2=\frac{4}{5}$.

Carry out the operations given on the arrows, and write the results on the corresponding dotted lines.

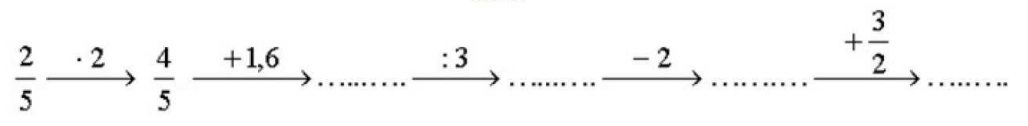

Figure 2. Exercise 1 of the entrance exam

According to Table 3, the solution of the problem requires the following mathematical competences: calculation, reading comprehension, attention and problem solving speed.

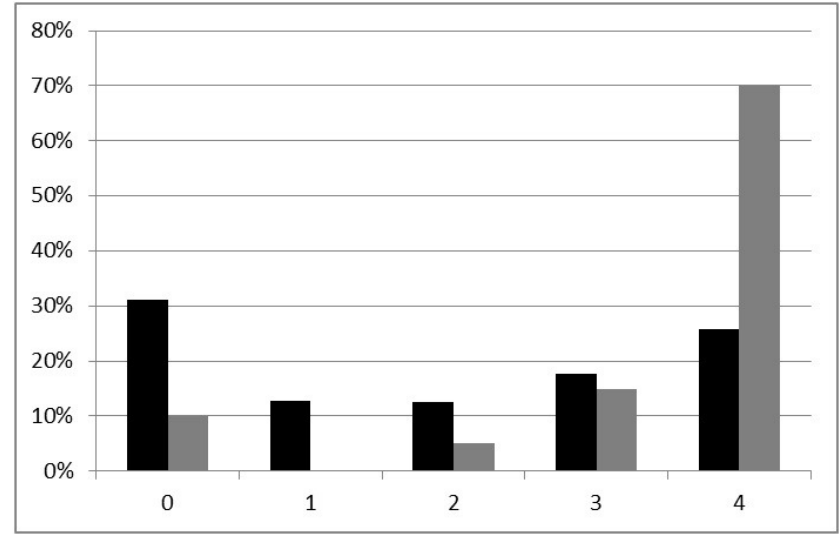

Figure 3. Relative frequency histogram of achieved points in Exercise 1

Figure 3 shows the relative frequencies of the achieved points in Exercise 1 (dark-grey: $\mathrm{nDB}$; light-grey: $\mathrm{CP}$ ). It is obvious, that the distributions of the achieved points (either for the $\mathrm{nDB}$, or for the $\mathrm{CP}$ samples) cannot be approximated by normal distributions. In the case of nDB-scores the first and last columns are rather high. This means that many students were not able to solve this problem, and again, many students could give the totally correct solution. The basic operations with rational numbers should be a routine task for 8th graders. Nevertheless, the drafting of the exercise distorts the picture because 
the result of the first step is the starting point of the second one. Students who could not solve the first step often didnot spend time on the second part, however partial points could have been given even if the result of the first step is wrong, but the calculations in the second one were correct. The number of perfect results was really high in case of the chess players. This experience is consistent with the assumption of Barrett and Fish[1] that chess develops the skill of correct calculation.

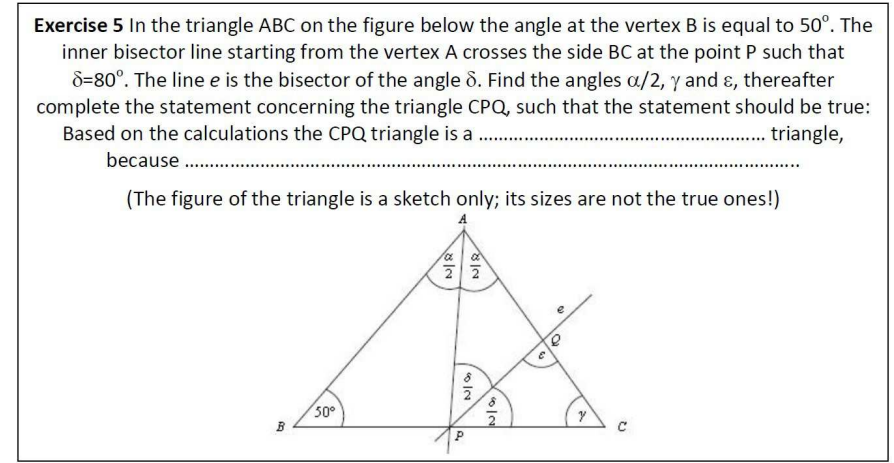

Figure 4. Exercise 5 of the entrance exam

According to Table 3,for the solution of Exercise 5 the following mathematical competences are required: reading comprehension, drawing - representation, partwhole perception, arguing - proving, memory, calculation and problem solving speed.

As Figure 5 shows, this geometrical exercise extremely differentiated students in the whole national database population (dark-grey: $\mathrm{nDB}$; light-grey: $\mathrm{CP}$ ). The phenomenon that many chess players solved the problem perfectly is clearly visible in this case, too. The solution requires knowledge about and application of the connections between triangles. These types of problems were also present in former tests, however, they could not be obviously considered as routine exercises because they require the unusual application and restructuration of the learnt schemes. A large scale of mathematical competence areas is required for the complete solution. Knowing the terms, definitions and their recognition with respect to the given triangle is required to answer the last question. The number of complete solutions in case of the experimental group shows a great difference against the results in the whole national database. 


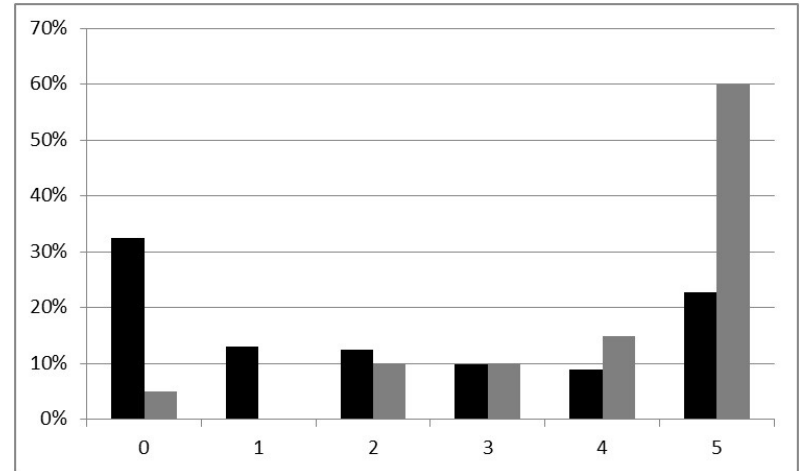

Figure 5. Relative frequency histogram of achieved points in Exercise 5

Exercise 8: On the marketplace of Neverhood we bought $12 \mathrm{~kg}$ first class apple. The price of a kilogram second class apple was $25 \%$ of the price of one $\mathrm{kg}$ first class apple. We had to pay 4176 coppers. What is the price (in copper $/ \mathrm{kg}$ ) of the first class apple and of the second class apple?

Figure 6. Exercise 8 of the entrance exam

According to Table 3 for the solution of Exercise 8 the following mathematical competences are required: reading comprehension, problem representation, originality-creativity, arguing-proving,quantitative reasoning,part-whole perception.

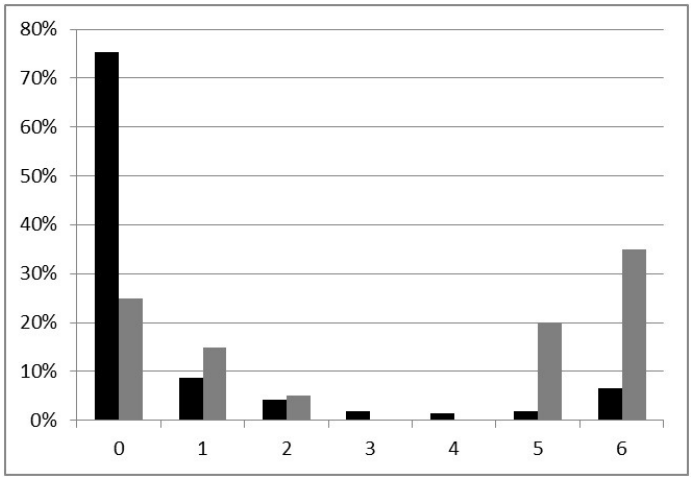

Figure 7. Relative frequency histogram of achieved points in Exercise 8 
This exercise requires ability for text-to-model (equation) creation. Solving this exercise caused difficulties country-wide. As Figure 7 shows, about $75 \%$ of the students achieved 0 point (dark-grey: nDB; light-grey: $\mathrm{CP}$ ). This problem divided chess players into two groups: more than half of the group scored 5-6 points.

From Table 3, we have chosen the competence areas occurring in most exercises. All the eleven chosen areas were investigated according as in which exercises, and inside that, in which items they appear. In this way, we could attach the scores (corresponding to the items) to these competence areas (Table 5).

Table 5. The national and the chess players' results divided between 11 competence areas

\begin{tabular}{|c|c|c|c|c|c|c|c|c|c|c|c|}
\hline & 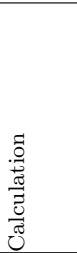 & $\begin{array}{l}0 \\
.0 \\
.00 \\
0 \\
0 \\
0 \\
0 \\
0 \\
.0 \\
0 \\
0\end{array}$ & 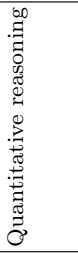 & 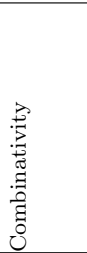 & 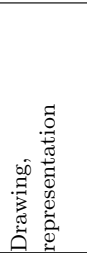 & 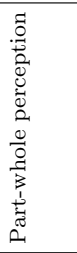 & 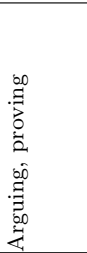 & 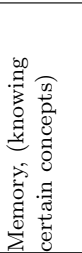 & 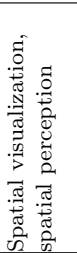 & 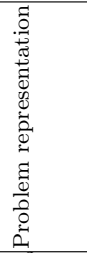 & 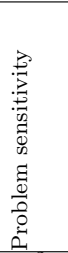 \\
\hline $\begin{array}{l}\text { Appearance } \\
\text { in the } \\
\text { exercises } \\
\text { and in their } \\
\text { items }\end{array}$ & $\begin{array}{l}1 \mathrm{a} \\
2 \mathrm{abcd} \\
4 \mathrm{bdf} \\
5 \mathrm{abc} \\
10 \mathrm{be}\end{array}$ & 2abcd & $\begin{array}{l}\text { 2abcd } \\
4 \text { ce } \\
8 \text { ade } \\
10 a c d\end{array}$ & $3 a$ & $\begin{array}{l}4 \mathrm{a} \\
5 \mathrm{abc}\end{array}$ & $\begin{array}{l}5 \mathrm{abc} \\
8 \mathrm{a} \\
9 \mathrm{a}\end{array}$ & $\begin{array}{l}5 \mathrm{abcd} \\
8 \mathrm{a} \\
9 \mathrm{a} \\
10 \mathrm{abcd}\end{array}$ & $\begin{array}{l}5 \mathrm{~d} \\
6 \mathrm{abcd} \\
7^{1}\end{array}$ & $\begin{array}{l}7^{2} \\
9^{2}\end{array}$ & $8^{2}$ & $10^{2}$ \\
\hline $\begin{array}{l}\text { Achievable } \\
\text { score }\end{array}$ & 16 & 4 & 15 & 5 & 4 & 14 & 21 & 7 & 11 & 6 & 5 \\
\hline $\begin{array}{l}\text { National } \\
\text { average }\end{array}$ & $50,9 \%$ & $62,6 \%$ & $32,8 \%$ & $63,2 \%$ & $54,8 \%$ & $19,9 \%$ & $21,1 \%$ & $62,2 \%$ & $7,4 \%$ & $9,1 \%$ & $1,4 \%$ \\
\hline $\begin{array}{l}\text { Chess - } \\
\text { players }\end{array}$ & $79,1 \%$ & $90,0 \%$ & $64,3 \%$ & $84,0 \%$ & $82,5 \%$ & $51,4 \%$ & $50,0 \%$ & $86,4 \%$ & $20,9 \%$ & $51,7 \%$ & $4,0 \%$ \\
\hline
\end{tabular}

The classification is based upon our long term experience in education, though it necessarily may involve certain subjective elements, as well. We performed the same steps in case of every competence area. For example, calculation skill is needed to solve exercises 1, 2, 4, 5 and 10, as given in Table 6 .

Both population scored the highest percentage (compared to themselves) in the fields of unit conversion, memory, and combinativity. These areas appeared in previous exams, too (routine exercises). The graph of Figure 8 clearly shows that the students of the chess player group performed better in all competence areas (dark-grey: nDB; light-grey: $\mathrm{CP}$ ). Their performance in problem representation is

\footnotetext{
${ }^{1} 1$ point if the score is not 0

2 the total score if it is at least 4
} 
Table 6 . The way of determination of the maximum score assigned to the competence area calculation

\begin{tabular}{|c|c|c|c|c|c|c|c|c|c|c|c|c|c|}
\hline Exercise & 1 & \multicolumn{4}{|c|}{2} & \multicolumn{4}{|c|}{4} & \multicolumn{3}{|c|}{5} & \multicolumn{3}{|c|}{10} \\
\hline Item & $\mathrm{a}$ & $\mathrm{a}$ & $\mathrm{b}$ & $\mathrm{c}$ & $\mathrm{d}$ & $\mathrm{b}$ & $\mathrm{d}$ & $\mathrm{f}$ & $\mathrm{a}$ & $\mathrm{b}$ & $\mathrm{c}$ & $\mathrm{b}$ & $\mathrm{e}$ \\
\hline Score & 4 & 1 & 1 & 1 & 1 & 1 & 1 & 1 & 1 & 1 & 1 & 1 & 1 \\
\hline
\end{tabular}

outstanding. (The previously demonstrated Exercise 8 requires this ability.) The highest difference between the two groups is at this point. This competence area only appeared in one single exercise, nevertheless states the results of Trinchero [19] and Kazemi, Yektayar and Abad (cited by Bart [2]) concerning mathematical problem solving. In problem sensitivity, spatial visualization-spatial perception, part-whole perception and arguing-proving chess players performed much better than other students. Our quantitative conclusion is more than two times the country-wide average.

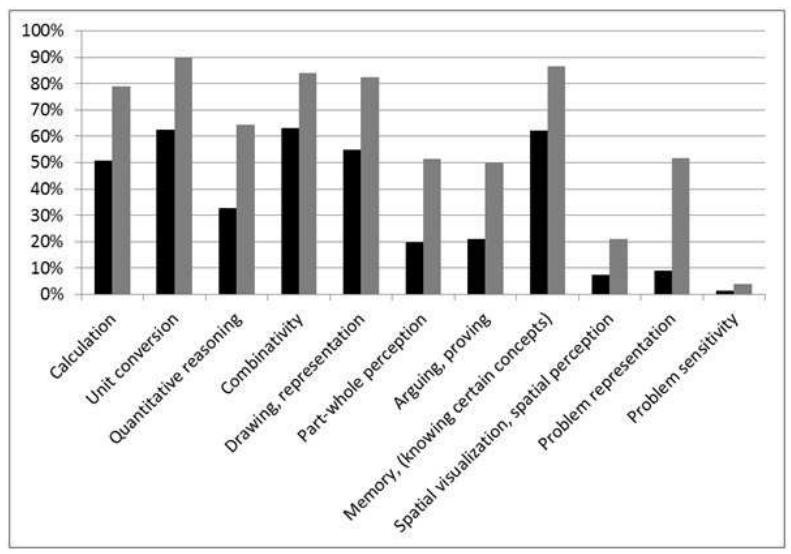

Figure 8. The dispersion of the analyzed competence areas

We talked over the solutions of the exam afterwards in detail and it turned out that every student of the experimental group could complete the exam in the given time. They used their leftover time to solve the more difficult problems and to check their answers. Solving sample exercises, the knowledge of routine exercises and the developed schemes played an important role in time management. 


\section{Summary}

In our paper, we were interested in the following questions. Is there some difference in the problem solving abilities of a chess player group with respect to other groups? Which are those mathematical competencies where chess players perform better?

The outcome of the mathematical entrance exam of Chess-players (who have been practicing chess course at least for a year, at most one hour a week) is significantly better than that of the two investigated group and the national average. This supports that learning and competing in chess from an early age may contribute to the better performance of pupils in mathematical problem solving.

With the analysis of the mathematical competence areas further research was aimed to the comparison of the results of the chess experimental group. Based upon the results obtained, some further conclusion may be drown: Chess-players performed better in more complex word problems that required more than one competence areas. Of the 11 analyzed competence areas the most outstanding was their performance in problem representation. In the fields of problem sensitivity, spatial visualization-spatial perception, part-whole perception, arguing-proving students of the experimental group greatly overachieved others.

\section{References}

[1] D. C. Barrett and W. W. Fish, Our move: Using chess to improve math achievement for students who receive special education services, International Journal of Special Education 26 (2011), 181-193.

[2] W. M. Bart, On the effect of chess training on scholastic achievement, Front Psychol. 5 (2014), 762.

[3] Chess in the schools, http://chessintheschools.org/s/index.cfm?SSID=1.

[4] Cs. Csíkos, Sakk, metakogníció és a kezdő-szakértő problematika, Hadmérnök, különszám "A sakk oktatásának hatása a képességfejlesztésre és a személyiségfejlesztésre" (2008), http://www.zmne.hu/hadmernok/kulonszamok/sakk_2007/htm/csikos.htm.

[5] Zs. Duró, A sakkoktatás hatásainak pedagógiai-pszichológiai vizsgálata, Fejlesztő Pedagógia 03-04 (2007), 100-111.

[6] Zs. Duró, A tehetséggondozás lehetőségei az iskolában a sakkoktatás képességfejlesztő hatásainak felhasználásával, in: Az iskola optimalizálásának lehetőségei, (I. Bábosik, ed.), Eötvös József Könyvkiadó, Budapest, 2013.

[7] Emberi Erőforrások Minisztériuma, NAT kerettanterv, Képességfejlesztő sakk kerettanterv 1-4. évfolyam számára, 23/2013. (III. 29.) EMMI rendelet 7.25., 2013. 
[8] J. J. Gik, Sakk és matematika, Gondolat, Budapest, 1989.

[9] S. Hong and W. Bart, Cognitive effects of chess instruction students at risk for academic failure, Int. J. Spec. Educ. 22 (2007), 89-96.

[10] L. Mérö, Észjárások - Remix - A racionális gondolkodás ereje és korlátai, Tericum, Budapest, 2008.

[11] A. Misetáné Burján and Gy. Birkás, Út a középiskolába..., Iskolakultúra 26, no. 6 (2016), 76-102.

[12] Oktatási Hivatal, Felvételi feladatsorok a 9. évfolyamra - 2014 - matematika, 2014, http://www.oktatas.hu/kozneveles/kozepfoku_felveteli_eljaras/ kozponti_feladatsorok/2014evi_9evfolyamra.

[13] Oktatási Hivatal, Tájékoztató a középfokú beiskolázás egységes írásbeli felvételi vizsgáinak - matematika és magyar nyelvi - feladatlapjairól, 2014, http://www.oktatas.hu/kozneveles/kozepfoku_felveteli_eljaras/ 2014_2015beiskolazas/irasbeli_vizsgak_feladatlapjairol.

[14] J. Polgár, Sakkpalota - Képességfejlesztő oktatási program, http://www . sakkpalota.hu/index.php/hu/sakkpalota-program.

[15] G. Sala, A. Gorini and Pravettoni, Mathematical Problem-Solving Abilities and Chess, An Experimental Study on Young Pupils, SAGE Open 5, no. 3 (2015).

[16] M. Scholz, H. Niesch, O. Steffen, B. Ernst, M. Loeffler, E. Witruk and H. Schwarz, Impact of chess training on mathematics performance and concentration ability of children with learning disabilities, Int. J. Spec. Educ. 23 (2008), 138-156.

[17] H. A. Simon and K. Gilmartin, A Simulation of Memory for Chess Positions, Cognitive Psychology 5, no. 1 (1973), 29-46.

[18] J. Sweller, R. E. Clark and P. A. Kirschner, Mathematical Ability Relies on Knowledge Too, American Educator Winter 2010 - 2011, 34-35.

[19] P. Szilágyi and Zs. Duró, Állomások és mérföldkövek - A sakk képességfejlesztő hatásainak kutatása külföldön és Magyarországon, Új Pedagógiai Szemle 57, no. 6 (2007), 12-44.

[20] R. Trinchero, Can Chess Training Improve Pisa Scores in Mathematics? An Experiment in Italian Primary School, Kasparov Chess Foundation Europe, Paris, 2013.

[21] T. Vidákovich, A matematikai kompetencia fejlesztésének koncepciója, SuliNova Kht., Budapest, 2005.

ANITA MISETÁNÉ BURJÁN

BÁTHORI U. 1.

BALATONLELLE

HUNGARY

E-mail: anitachess64@gmail.com

(Received June, 2016) 